\title{
Pengaruh Perceived Ease Of Use dan Perceived Usefulness terhadap Penggunaan Teknologi Marketplace dengan Attitude sebagai Variabel Intervening (Studi Pada UMKM di Kota Malang)
}

\author{
Uke Prajogo
}

STIE Malangkucecwara, Indonesia

\section{Info Artikel}

Riwayat Artikel

Diterima: 16-06-2021

Direvisi: $17-06-2021$

Disetujui: 01-07-2021

\section{Kata Kunci \\ perceived ease of use; perceived usefulness; attitude; \\ teknologi marketplace;}

\section{Corresponding Author}

Uke Prajogo,

STIE Malangkucecwara,

Tel. +62 81235084536

ukeprajogo@stie-mce.ac.id

\begin{abstract}
ABSTRAK
Tujuan yang ingin dicapai dari hasil penelitian ini adalah untuk menjelaskan dan menganalisis pengaruh perceived ease of use dan perceived usefulness terhadap penggunaan teknologi marketplace dengan attitude sebagai variabel intervening. Jenis penelitian yang digunakan adalah explanatory research. Sampel dalam penelitian ini adalah 84 orang responden yang menjadi pemilik UMKM diambil secara incidental sampling. Instrumen penelitian dengan menggunakan kuesioner. Analisis yang digunakan adalah analisis regresi linier berganda, dimana X1 menunjuk pada variabel perceived ease of use, X2 pada perceived usefulness, $\mathrm{Y} 1$ pada attitude, dan $\mathrm{Y} 2$ pada penggunaan teknologi marketplace. Berdasarkan hasil penelitian disimpulkan bahwa market oriented dan entrepreneurship berpengaruh positif dan signifikan terhadap keunggulan bersaing dan kinerja pemasaran. Market oriented dan entrepreneurship yang lebih baik akan meningkatkan keunggulan bersaing dan kinerja pemasaran. Keunggulan bersaing berpengaruh positif dan signifikan terhadap kinerja pemasaran.
\end{abstract}

\section{PENDAHULUAN}

Pada masa pandemi Covid-19, jumlah pengguna internet di Indonesia meningkat menjadi 196,7 juta jiwa hingga kuartal II Tahun 2020. Sedangkan pada Tahun 2018 lalu, jumlah pengguna internet di Indonesia hanya sebesar 171,2 juta jiwa. Hal tersebut diketahui berdasarkan hasil survei yang dilakukan oleh Asosiasi Penyelenggara Jasa Internet Indonesia (APJII). Survei tersebut dilakukan pada Tanggal 2 Juni sampai 25 Juni 2020. Transaksi online pada pengguna internet di Indonesia pada Bulan Agustus 2020 juga naik sangat tinggi hingga mencapai 140 juta transaksi, dibandingkan Bulan Tahun 2019 yang mencapai 80 juta transaksi maupun Bulan Agustus Tahun 2018 yang mencapai 40 juta transaksi.

Transaksi online yang populer di kalangan masyarakat Indonesia adalah berbasis marketplace yaitu penjual dan pembeli dapat langsung bertransaksi pada suatu tempat. Terdapat ratusan website marketplace yang ada di Indonesia, namun ada beberapa marketplace yang cukup terkemuka seperti Shopee, Tokopedia, Bukalapak, Lazada dan lain lain. Platform marketplace dalam negeri merajai pasar belanja online di Indonesia. Hal tersebut berdasarkan data SimilarWeb kategori marketplace di Indonesia. Dari data tersebut, selama periode Januari Tahun 2021, Tokopedia memimpin dengan traffic share sebesar 32,04\%. Jumlah kunjungan bulanan ke layanan marketplace tersebut sebanyak 129,1 juta. Porsi kunjungan melalui mobile phone mendominasi sebesar 62,7 \%, sedangkan 
dari desktop 37,3\%. Rata-rata durasi kunjungan 6 menit 37 detik. Kemudian di peringkat kedua ditempati Shopee dengan traffic share sebesar 29,78 \%. Jumlah kunjungan bulanan sebanyak 120 juta. Shopee paling banyak diakses melalui mobile phone 72,4\% dan desktop 21,3\%. Rata-rata durasi kunjungan 6 menit 30 detik. Sementara Bukalapak di peringkat ketiga dengan traffic share 8,23 \%. Jumlah kunjungan bulanan sebanyak 13,58 juta. Bukalapak paling banyak diakses melalui mobile phone 78,7 \%, sedangkan desktop 21,3\%. Rata-rata waktu kunjungan 4 menit 10 detik. Peringkat lima besar lain ditempati Lazada dengan traffic share 7,11 \%. Kunjungan bulanan sebanyak 28,66 juta. Lazada paling banyak diakses melalui mobile phone 80,7 \% dan desktop 19,3\%. Rata-rata kunjungan 6 menit 34 detik. Peringkat lima besar ditutup oleh Blibli dengan traffic share 4,22 \%. Jumlah kunjungan bulanan sebanyak 16,99 juta. Blibli paling banyak diakses melalui mobile phone dengan porsi 64,7 \% dan desktop 35,3\%. Rata-rata durasi kunjungan 3 menit. Peringkat enam hingga 10 secara berurutan ditempati oleh iPrice, Amazon, Cekresi, Ralali, dan JD.ID. Pandemi menjadi momentum tersendiri bagi industri marketplace.

Dalam marketplace terdapat salah satu proses yang harus di lakukan oleh konsumen, yaitu sistem pembayaran. Menurut Bank Indonesia sistem pembayaran adalah sistem yang berkaitan dengan kegiatan pemindahan dana dari satu pihak kepada pihak lain yang melibatkan berbagai komponen sistem pembayaran. Sistem pembayaran di marketplace berlaku sistem pembayaran elektronik, Menurut Aigbe dan Akpojaro [7] sistem pembayaran elektronik (Electronic Payment System) adalah sistem pertukaran uang antara pembeli dan penjual di lingkungan online yang difasilitasi oleh instrumen keuangan digital (seperti nomor kartu kredit terenkripsi, cek elektronik, atau uang digital) yang didukung oleh bank, sebuah perantara atau dengan tender legal. Di dalam sistem pembayaran elektronik marketplace terdapat beberapa jenis pembayaran yaitu internet banking, kartu kredit online, kartu debit online, transfer bank, digital wallet dan tunai digital. Sistem pembayaran elektronik menjadi hal yang penting dalam marketplace karena sebagus apapun plan bisnis serta desain dari marketplace jika sistem pembayaran elektroniknya tidak ease of use dan usefulness maka transaksi akan terhambat.

Usaha kecil menengah (UKM) memiliki beberapa keterbatasan, salah satunya cakupan pasar yang relatif terbatas. Produk pada UKM juga relatif kurang dikenali dan hanya digunakan oleh masyarakat sekitar, di mana sudah sejak lama mereka terlibat kerja sama transaksional. [12] menyatakan bahwa attitude UKM cenderung menggantungkan permintaan produknya pada sejumlah kecil pelanggan. Namun, pada era persaingan bisnis saat ini UKM berpeluang untuk dapat mengakomodir pasar yang lebih luas jika mampu beradaptasi dengan perkembangan teknologi. Ketika produk dikenal oleh lebih banyak orang maka peluang terjadinya transaksi akan jauh lebih besar. Perdagangan dengan sistem online memungkinkan penyederhanaan aktivitas transaksi, pelanggan dapat melakukan pemesanan tanpa terkendala oleh faktor tempat dan waktu.

\section{METODE}

Jenis penelitian yang digunakan adalah explanatory research. Sampel dalam penelitian ini adalah 80 orang responden yang menjadi pemilik UMKM diambil secara incidental sampling. Instrumen penelitian dengan menggunakan kuesioner. Analisis yang digunakan adalah analisis regresi linier berganda, dimana $\mathrm{X} 1$ menunjuk pada variabel perceived ease of use, X2 pada perceived usefulness, Y1 pada attitude, dan Y2 pada penggunaan teknologi marketplace.

Penelitian ini menggunakan Technology Acceptance Model [1] sebagai landasan teori dalam adopsi informasi teknologi yang berupa marketplace oleh UMKM. Menurut Davis 
[1], TAM adalah sebuah teori sistem informasi yang dirancang untuk menjelaskan bagaimana pengguna mengerti dan menggunakan sebuah teknologi informasi. TAM menggunakan Theory of Reason Action (TRA) sebagai dasar teoritikal yang digunakan untuk melihat bagaimana tingkat adopsi responden dalam menerima teknologi informasi. Dalam TRA, Ajzen mengemukakan bahwa niat melakukan atau tidak melakukan perilaku tertentu dipengaruhi oleh dua variabel dasar, yang pertama sikap (Attitude) dan yang kedua adalah norma subjektif (Subjective Norms). Variabel yang lain dalam TRA adalah keyakinan terhadap perilaku (Behavioural Beliefs) dan keyakinan normatif (Normative Beliefs). Dalam memformulasikan TAM, Davis tidak mengakomodasi semua komponen teori TRA, Davis hanya memanfaatkan komponen "Belief dan Attitude" saja, sedangkan Normative Belief dan Subjective Norms tidak digunakannya [1].

Menurut Davis [1] perilaku menggunakan suatu teknologi diawali oleh adanya persepsi mengenai manfaat (perceived usefulness) dan persepsi mengenai kemudahan penggunaan suatu teknologi (perceived ease of use). Kedua komponen ini bila dikaitkan dengan TRA adalah bagian dari belief. Persepsi terhadap manfaat (perceived usefulness) adalah manfaat yang diyakini individu dapat diperolehnya apabila menggunakan suatu teknologi. Variabel lain yang dikemukakan Davis [2] mempengaruhi kecenderungan individu menggunakan suatu teknologi adalah persepsi terhadap kemudahan (perceived ease of use) dalam penggunaan suatu teknologi. Kemudahan (perceived ease of use) bermakna tanpa kesulitan atau terbebaskan dari kesulitan atau tidak perlu berusaha keras. Dengan demikian persepsi mengenai kemudahan dalam penggunaan suatu teknologi merujuk pada keyakinan individu bahwa sistem teknologi yang akan digunakan tidak merepotkan atau tidak membutuhkan usaha yang besar pada saat digunakan. Persepsi terhadap manfaat teknologi (perceived usefulness) dan persepsi terhadap kemudahan penggunaan teknologi (perceived ease of use) mempengaruhi sikap (attitude) individu terhadap penggunaan teknologi, yang selanjutnya akan menentukan apakah orang memutuskan untuk penggunaan teknologi (actual usage).

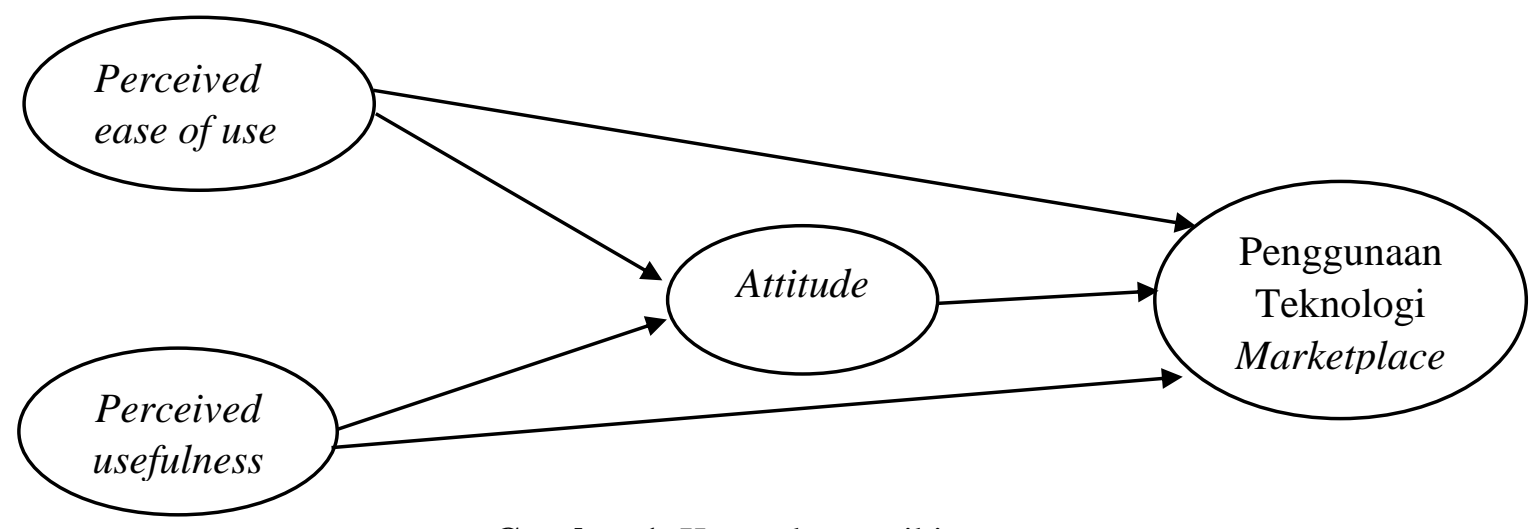

Gambar 1. Kerangka pemikiran

\section{Hipotesis}

Berdasarkan telaah pustaka dan kerangka pemikiran teoritis, maka hipotesis yang diajukan dalam penelitian ini adalah :

Hipotesis 1 :

Perceived ease of use tidak berpengaruh terhadap penggunaan teknologi marketplace.

Hipotesis 2 :

Perceived usefulness tidak berpengaruh terhadap penggunaan teknologi marketplace. 
Hipotesis 3 :

Perceived ease of use berpengaruh terhadap penggunaan teknologi marketplace dengan attitude sebagai mediator

Hipotesis 4 :

Perceived usefulness berpengaruh terhadap penggunaan teknologi marketplace dengan attitude sebagai mediator

\section{HASIL DAN PEMBAHASAN}

\section{Pengaruh Perceived ease of use terhadap Penggunaan Teknologi Marketplace}

Persamaan regresi tersebut menunjukkan bahwa nilai koefisien perceived ease of use (X1) sebesar 0,237 yang berarti apabila perceived ease of use (X1) meningkat satu satuan maka penggunaan teknologi marketplace (Y2) akan meningkat 0,237 satuan. Hasil statistik uji t untuk variabel perceived ease of use diperoleh nilai t hitung sebesar 2,245 dengan tingkat signifikansi 0,012, karena signifikansi lebih kecil dari 0,05 $(0,012<0,05)$, dan koefisien regresi mempunyai nilai positif sebesar 0,237, maka Hipotesis 1 yang menyatakan bahwa "Perceived ease of use tidak berpengaruh terhadap penggunaan teknologi marketplace" diterima.

Besarnya pengaruh perceived ease of use terhadap penggunaan teknologi marketplace sebesar 0,105; hal ini berarti bahwa penggunaan teknologi marketplace dipengaruhi oleh perceived ease of use sebesar 10,5\%, sedangkan sisanya sebesar 89,5 dipengaruhi oleh faktor lain. Perceived ease of use tidak mempengaruhi penggunaan teknologi marketplace. Hal ini mengindikasikan bahwa penerimaan terhadap suatu teknologi, dalam hal ini mengadopsi marketplace oleh para pelaku UKM, tidak hanya dipengaruhi oleh perceived ease of use. Faktor lain yang bisa mempengaruhi sikap penerimaan terhadap penggunaan teknologi marketplace.

\section{Pengaruh Perceived usefulness terhadap Penggunaan Teknologi Marketplace}

Hasil persamaan regresi tersebut menunjukkan bahwa nilai koefisien perceived usefulness (X2) sebesar 0,325 yang berarti apabila perceived usefulness (X2) meningkat satu satuan maka penggunaan teknologi marketplace (Y2) akan meningkat 0,325 satuan. Hasil statistik uji t untuk variabel perceived usefulness diperoleh nilai t hitung sebesar 3,215 dengan tingkat signifikansi 0,000, karena signifikansi lebih kecil dari 0,05 $(0,000<0,05)$, dan koefisien regresi mempunyai nilai positif sebesar 0,325 ; maka Hipotesis 2: "Perceived usefulness tidak berpengaruh terhadap penggunaan teknologi marketplace" diterima.

Besarnya pengaruh perceived usefulness terhadap penggunaan teknologi marketplace sebesar 0,102; hal ini berarti bahwa penggunaan teknologi marketplace dipengaruhi oleh perceived usefulness $10,2 \%$, sedangkan sisanya sebesar $89,8 \%$ dipengaruhi oleh faktor lain bahwa terdapat pengaruh market oriented terhadap keunggulan bersaing. Hal ini didukung dengan nilai koefisien regresi adalah sebesar 0,180 dan nilai t hitung sebesar 2,198 >t tabel dengan tingkat signifikan $(0,031)<0,05$. Dengan demikian dapat disimpulkan bahwa hipotesis ketiga diterima. Dengan demikian dalam penelitian ini ditemukan bahwa ada pengaruh yang positif dan signifikan market oriented terhadap keunggulan bersaing.

Perceived usefulness tidak mempengaruhi penggunaan teknologi marketplace. Hal ini mengindikasikan bahwa penerimaan terhadap suatu teknologi, dalam hal ini mengadopsi marketplace oleh para pelaku UKM, tidak hanya dipengaruhi oleh perceived usefullness. Faktor lain yang bisa mempengaruhi sikap penerimaan terhadap penggunaan teknologi marketplace.

Pengaruh Perceived ease of use terhadap Penggunaan Teknologi Marketplace melalui Attitude 
Hasil persamaan regresi menunjukkan bahwa nilai koefisien perceived ease of use (X1) terhadap penggunaan teknologi marketplace (Y2) sebesar 0,954 yang berarti apabila perceived ease of use (X1) meningkat satu satuan maka penggunaan teknologi marketplace (Y2) akan meningkat 0,943 satuan dengan attitude sebagai mediator (Y1). Hasil statistik uji t untuk variabel perceived ease of use diperoleh nilai t hitung sebesar 9,075 dan sig $0,000<0,05$. Artinya Hipotesis 3 : "Perceived ease of use berpengaruh terhadap penggunaan teknologi marketplace dengan attitude sebagai mediator" diterima.

Besarnya pengaruh perceived ease of use terhadap penggunaan teknologi marketplace dengan attitude sebagai mediator sebesar 79,9\%. Besarnya pengaruh tersebut menunjukkan bahwa fungsi attitude sebagai mediator penggunaan teknologi marketplace sangat penting. Perceived ease of use yang ditawarkan suatu teknologi akan mempengaruhi sikap penerimaan atau penolakan seseorang dalam mengadopsi suatu teknologi. Perceived ease of use pada teknologi marketplace seperti kemudahan dan kepraktisan untuk menginstall aplikasi, kemudahan pengoperasian, kemudahan dan fleksibilitas sistem pembayaran elektronik, kemudahan berkomunikasi dengan pembeli, kemudahan dan fleksibilitas dalam memilih perusahaan kurir mendorong para pelaku UKM untuk mau menerima dan mengadopsi teknologi marketplace dalam aktivitas bisnisnya. Hasil dalam penelitian ini sekaligus mengindikasikan bahwa perceived ease of use yang ditawarkan suatu teknologi akan mempengaruhi kecenderungan seseorang untuk menggunakan teknologi tersebut.

Hasil penelitian ini selaras dengan beberapa penelitian yang menunjukkan bahwa perceived ease of use (kemudahan) berpengaruh terhadap penggunaan teknologi [3], [4], [5], sehingga semakin baik persepsi pengguna tentang kemudahan penggunaan yang terbentuk maka semakin positif perilaku konsumen yang menggunakan layanan yang disediakan. Menurut Adhiputra [3] mendefinisikan persepsi kemudahan penggunaan (perceived ease of use) merupakan suatu kepercayaan tentang proses pengambilan keputusan dalam menggunakan teknologi informasi. Menurut Davis dalam Hartono dikatakan bahwa didalam TAM mengkonsepkan attitude sebagai sikap terhadap penggunaan sistem yang berupa penerimaan ataupun penolakan sebagai dampak apabila seseorang menggunakan teknologi informasi dalam pekerjaannya.

Dari teori diatas dapat dinyatakan bahwa sikap seseorang dapat dilihat dari keyakinan/kepercayaan yang dimiliki serta pilihan seseorang terhadap suatu layanan yang digunakan. Jika seseorang telah mempercayai bahwa teknologi marketplace tersebut mudah untuk digunakan dan dapat memenui kebutuhan-kebutuhannya, maka seseorang tersebut akan menunjukkan perilaku yang positif untuk menerima dan menggunakan layanan tersebut.

\section{Pengaruh Perceived usefulness terhadap Penggunaan Teknologi Marketplace Melalui Attitude}

Hasil Persamaan regresi menunjukkan bahwa nilai koefisien perceived usefulness (X2) terhadap penggunaan teknologi marketplace (Y2) melalui attitude (Y1) sebesar 0,957 yang berarti apabila perceived usefulness (X2) meningkat satu satuan maka penggunaan teknologi marketplace (Y2) akan meningkat 0,957 satuan dengan attitude (Y1) sebagai mediator.

Hasil statistik uji t untuk variabel perceived usefulness diperoleh nilai t hitung sebesar 8,256 dan sig $0,000<0,05$. Artinya Hipotesis 4: "Perceived usefulness berpengaruh terhadap penggunaan teknologi marketplace dengan attitude sebagai mediator" diterima. 
Besarnya pengaruh perceived usefulness terhadap penggunaan teknologi marketplace dengan attitude sebagai mediator sebesar $82,6 \%$. Besarnya pengaruh tersebut menunjukkan bahwa fungsi attitude sebagai mediator penggunaan teknologi marketplace sangat penting.

Perceived usefulness yang ditawarkan suatu teknologi akan mempengaruhi sikap penerimaan atau penolakan seseorang dalam mengadopsi suatu teknologi. Perceived usefulness yang ditawarkan marketplace seperti: proses transaksi yang cepat, jangkauan pelayanan yang luas, jaminan keamanan transaksi jual beli, jaminan kualitas dan ketersediaan, biaya komisi yang rendah, program diskon, program bebas biaya pengiriman akan mendorong para pelaku UMKM untuk mau menerima dan mengadopsi marketplace dalam aktivitas bisnisnya. Hasil dalam penelitian ini sekaligus mengindikasikan bahwa perceived usefulness yang ditawarkan suatu teknologi akan mempengaruhi kecenderungan seseorang untuk tetap menggunakan teknologi. Informasi terkait teknologi marketplace yang ditawarkan akan mendorong attitude para pelaku UMKM untuk mengadopsi teknologi marketplace dalam aktivitas bisnisnya seperti: mempermudah transaksi penjualan, mengetahui keinginan konsumen serta memperluas pemasaran produknya.

Hasil penelitian ini sesuai dengan hasil penelitian [6], [7], [8], [9] yang menyatakan adanya hubungan positif yang konsisten antara perceived usefulness terhadap attitude dan penggunaan teknologi. Sikap penerimaan terhadap suatu teknologi akan mempengaruhi keinginan seseorang untuk menerapkan atau menggunakan teknologi tersebut [10]. Para pelaku UMKM yang menerima untuk mengadopsi marketplace maka mereka menginginkan untuk mengaplikasikan marketplace dalam aktivitas bisnisnya [11]. Hasil penelitian menunjukkan UMKM rata-rata melakukan transaksi melalui marketplace minimal 5 kali dalam sebulan.

\section{SIMPULAN DAN SARAN}

Hasil temuan penelitian ini adalah attitude memediasi secara penuh perceived ease of use dan perceived usefulness terhadap penggunaan teknologi marketplace. Secara khusus hasil penelitian ini dapat disimpulkan sebagai berikut.

1. Variabel perceived ease of use tidak berpengaruh langsung tarhadap penggunaan teknologi marketplace. Hal ini menunjukkan terkait ease of use (kemudahan) yang ditawarkan teknologi marketplace, pemilik UMKM tidak akan menggunakan teknologi marketplace jika teknologi tersebut tidak sesuai dengan karakteristik dan kebutuhan UMKM.

2. Variabel perceived usefulness tidak berpengaruh langsung terhadap penggunaan teknologi marketplace. Hal ini menunjukkan terkait usefulness (manfaat) yang ditawarkan teknologi marketplace, pemilik UMKM tidak akan menggunakan teknologi marketplace jika manfaat teknologi tersebut tidak sesuai dengan yang diharapkannya.

3. Variabel perceived ease of use berpengaruh terhadap penggunaan teknologi marketplace jika melalui variabel attitude sebagai mediator. Hal ini menunjukkan berdasarkan variabel perceived ease of use, perceived ease of use pada teknologi marketplace seperti kemudahan dan kepraktisan untuk menginstall aplikasi, kemudahan pengoperasian, kemudahan dan fleksibilitas sistem pembayaran elektronik, kemudahan berkomunikasi dengan pembeli, kemudahan dan fleksibilitas dalam memilih perusahaan kurir akan mendorong para pelaku UKM untuk mau menerima dan mengadopsi teknologi marketplace dalam aktivitas bisnisnya.

4. Variabel perceived usefulness berpengaruh terhadap penggunaan teknologi marketplace jika melalui variabel attitude sebagai mediator. Hal ini menunjukkan berdasarkan variabel perceived usefulness, perceived usefulness yang ditawarkan teknologi marketplace seperti: proses transaksi yang cepat, jangkauan pelayanan yang luas, jaminan keamanan transaksi jual beli, jaminan kualitas dan ketersediaan, biaya komisi 
yang rendah, program diskon, program bebas biaya pengiriman akan mendorong para pelaku UMKM untuk mau menerima dan mengadopsi marketplace dalam aktivitas bisnisnya.

\section{DAFTAR PUSTAKA}

[1] F. D. Davis, "Perceived Usefulness, Perceived Ease Of Use And User Acceptance Of Information Technology”, MIS Quarterly, Vol. 13 No.3, pp. 318-39, 1986.

[2] F. D. Davis, "Measurement Scales for Perceived Usefulness and Perceived Ease of Use", 1986. http://wings.buffalo.edu/mgmt/courses/mgtsand/success/davis.html, (retrieved 23 Desember 2005) dasril.wordpress.com/e-commerce.

[3] M. W. Adhiputra, "Aplikasi Technology Acceptance Model terhadap Pengguna Layanan Internet Banking”, Jurnal Bisnis dan Komunikasi, 2 (1), 52 - 63, 2015.

[4] U. Prajogo, "Rancangan Model Pengembangan Kewirausahaan pada Mahasiswa Ditinjau dari Persepsi, Minat dan Kompetensi Kewirausahaan”, Jurnal Manajemen dan Kearifan Lokal Indonesia (JMKLI), Volume 1, No. 1, page 59 - 70, 2017.

[5] B. A. Yuliyani \& M. S. Dewi, "Generasi Y dan Adopsi terhadap Internet Banking pada Nasabah di Indonesia Menggunakan Kerangka Technology Acceptance Model (TAM)", Jurnal Wawasan Manajemen, 4 (3), 231 - 244, 2016.

[6] U. Prajogo, Armanu \& Rofiaty, "The Influence Of Psychological Toward Consumers Adoption Of Innovation With Consumer Innovativeness As Mediators (Study Of Cellular Telephone Consumers In Malang City)", International Journal of Civil Engineering and Technology (IJCIET), Volume 9, Issue 11, November 2018, pp. 1130-1147, 2018.

[7] Arya Nugraha \& Herry Laksito, “Anteseden Penerimaan Teknologi Informasi Dalam Profesi Audit Internal Dengan Menggunakan Technology Acceptance Model (Studi Empiris Pada Bank Perkreditan Rakyat Di Jawa Tengah)", Diponegoro Journal Of Accounting, Volume 3, Nomor 2, Tahun 2014, Halaman 1-15, 2014.

[8] R. P. Bangkara \& N. P. S. H. Mimba, "Pengaruh Perceived Usefulness Dan Perceived Ease Of Use Pada Minat Penggunaan Internet Banking Dengan Attitude Toward Using Sebagai Variabel Intervening”, E-Jurnal Akuntansi Universitas Udayana, Vol. 16.3, September (2016): 2408-2434, 2016.

[9] E. I. Tyas \& E. S. Darma, "Pengaruh Perceived Usefulness, Perceived Ease of Use, Perceived Enjoyment, dan Actual Usage Terhadap Penerimaan Teknologi Informasi: Studi Empiris Pada Karyawan Bagian Akuntansi dan Keuangan Baitul Maal Wa Tamwil Wilayah Daerah Istimewa Yogyakarta dan Sekitarnya", Reviu Akuntansi dan Bisnis Indonesia, Vol. 1 No. 1, Hlm: 25-35, 2017.

[10] U. Prajogo, M. Lutfi, Y. Liana, and A. Sutanto, "Evaluation of post-harvest coffee to conform with good manufacturing practices (GMP) to develop entrepreneurship", Published under licence by IOP Publishing Ltd. IOP Conference Series: Earth and Environmental Science, Volume 475, International Conference on Green Agro-industry and Bioeconomy 26-27 August 2019, Malang East Java Indonesia, 2020.

[11] U. Prajogo, "Pengaruh Entrepreneurship dan Market Oriented Terhadap Keunggulan Bersaing untuk Peningkatan Kinerja Online Shop UMKM", Jurnal Teknologi dan Manajemen Informatika (JTMI), Volume 6, Issue 2, pages 147 - 152, 2020.

[12] Hadiyati. 2010. Pemasaran Untuk UMKM. (Teori dan Aplikasi). Jilid 1. Bayu Media Publishing, Malang, Indonesia 